\title{
THE ANALYSIS OF THE TYPES OF COMMUNICATION STRATEGY USED BY THE TEACHER IN TEACHING THE SEVENTH GRADE STUDENTS OF SMP LAB UNIVERSITAS PENDIDIKAN GANESHA
}

\author{
D.A.B Suari \\ Ganesha University of Education \\ Banjar Padang Tegal Tengah, Kec. Ubud, Kab. Gianyar \\ Gmail: dwayuace@gmail.com
}

\begin{abstract}
Abstrak
Penelitian ini bertujuan untuk mendeskripsikan tipe strategi komunikasi yang digunakan oleh guru Bahasa Inggris di SMP LAB Singaraja dalam mengajarkan bahasa inggris kepada siswa kelas VII, tipe strategi komunikasi yang paling sering digunakan dan alasan dalam menggunakannya. Penelitian ini merupakan penelitian kualitatif deskiptif. Subjek dari penelitian ini adalah guru Bahasa Inggris di SMP LAB yang mengajar siswa kelas VII. Data dikumpulkan dengan perekaman video, wawancara, dan lembar observasi. Hasil dari penelitian ini menunjukkan bahwa tes pemahaman paling sering digunakan dengan jumlah 7 kali, diikuti dengan perubahan bahasa yang terjadi sebanyak 5 kali, penggunaan padanan kata sebanyak 4 kali, bahasa isyarat 3 kali, pengalihan topik 2 kali serta penggunaan klarifikasi dan penjelasan tambahan terjadi masing - masing 1 kali.
\end{abstract}

Kata kunci: strategi komunikasi, siswa kelas VII

\section{Abstract}

This study aimed at describing the types of communication strategy used by the teacher of SMP $\angle A B$ Singaraja in teaching seventh grade students, the most frequent types of communication strategy used and the teacher's reasons in using those strategies. This study was designed as a descriptive qualitative. The sample of this study was a teacher in SMP Lab Singaraja who teaches the seventh grade students in that school. The data was collected by field recording, interview, and observation sheet. The result of this study shows that comprehension check was the most frequent strategy used in the learning process with total occurrence of 7 times, followed by language switching 5 times, approximation 4 times, paralanguage 3 times, topic avoidance 2 times and then both clarification request and circumlocution occurred 1 time.

Key Words: communication strategies, seventh grade student

\section{INTRODUCTION}

Language is the communication tool of human beings which is one of the most important ways of expressing ourselves, communicating with people, planning our lives, remembering the past, exchanging ideas and preferences. The ability to know more than one language develops the opportunities for people to experience these functions and even master them as well as advancing their career opportunity. Penny McKay (2008) states that recent years have seen considerable growth in the number of the children learning a second or foreign language, as the importance of being able to use a language other than one's first language has become recognized in an increasingly globalized world. In Asia, there has been a tendency to lower the age at which school children begin to learn a foreign language. It is believed that the earlier a child starts to learn a foreign language, the greater the ultimate achievement will be. But, the importance of the native language itself could not be neglected. 
Being able to speak foreign language have to be balanced with the knowledge of their mother tongue.

To teach English as Foreign Language (EFL) in non-speaking English country is not easy. The teacher should have a great mastery of English as well as a creative mind to create interesting and applicable lessons. It is difficult because the students would not have enough time to practice English in their daily life. A language will be easier to be mastered when you use it in your daily life. Students only learn English for four hours a week in the classroom. Not all of the students take additional English course outside the school. Therefore, their mastery of English when they stepped in the secondary school cannot be counted as enough.

This study aimed at describing the types of communication strategy used by the English teacher of SMP LAB Singaraja in teaching seventh grade students, the most frequent types of communication strategy used and the teacher's reasons in using those strategies.

\section{RESEARCH METHODS}

This study employed qualitative research design. This research aimed at describing the types of communication strategy used by the teacher of SMP LAB Singaraja in teaching seventh grade students, the most frequent types of communication strategy used and the teacher's reasons in using those strategies. The subject of the study was the English teacher who teaches the seventh grade students in SMP LAB Singaraja. The object of the study were: types of communication strategy used by the teacher in teaching seventh grade students, communication strategy that is most frequently used, and the reasons why the teacher uses those types of communication strategy in the learning process.

In obtaining the data, , there are five types of instruments that the researcher used to gather the data in this study, namely human instrument, video recorder, field note, observation sheet, interview guide. Human instrument in this study was the writer-herself since the researcher act as non-participant observer during the process of collecting the data.

In this study, the subject of the study was the English teacher who teaches seventh grade students in SMP LAB Singaraja.

The data were collected through observationand interview techniques. The type of observation which had been done was non-participant observation in which the researcher directly observed and captured the data in the form of recorded data.. The researcher directly visited SMP LAB Singaraja and observed the classes taught by the teacher. The learning processes were recorded with video recorder. The second method was interview. The interview had been conducted to the teacher. It had two main purposes. The first was to investigate the teacher reasons in applying communication strategies. The second was to find more complete data when interesting findings found. This method was used to answer the first and third research questions.

The data which had been obtained were analyzed in order to answer the research questions. There were six steps which had been done in analyzing the data.The first step, all recorded 
data gained from the observation were transcribed into written form to enable the researcher analyze the data in form of utterances. The second step, the transcribed data were analyzed. The utterances were classified into types of communication strategies proposed by various experts. The third step, the data gained from observation which had been classified were analyzed and accumulated in order to know the communications strategies which were used most frequently by the teacher. The fourth step, all recorded data gained from the interviews were transcribed into written form. Then, the transcribed data of the interview and field note were analyzed to investigate the teacher' reasons in applying particular communication strategies. The last step was triangulation.

The triangulation was done by comparing the findings from the results of interviews, the results of observations and the researcher point of view.

\section{FINDING AND DISCUSSION}

There were seven types of communication strategies used by the teacher in teaching English for seventh grade students. They were comprehension check, language switching, approximation, topic avoidance, clarification request, paralanguage, circumlocution. First, approximation is one of the communication strategies used by the teacher. The teacher tried to use similar word in order to get the students comprehension and also to make students caught the referred word themselves. It was found that the teacher guided the students with phrase "not clean your shoes" to make them answering "to polish your shoes".

$\mathrm{T} \quad$ : Yang lain.. Ini kan mem-polishing your shoes..

S3 : How to clean your shoes (while smiling)

T : No.. Not clean. But.. How to.. How to polish your shoes.

$S \quad$ : How to polish your shoes.

The teacher used another words which have similar meaning to help the students understand. The word polish that she wanted to produce by the students, although a bit difficult, the teacher guided it with the word 'clean'.

Second, circumlocution deals with telling difficult word by giving more words than necessary to explain a word. It was found that the teacher used difficult word and then described it with more words.

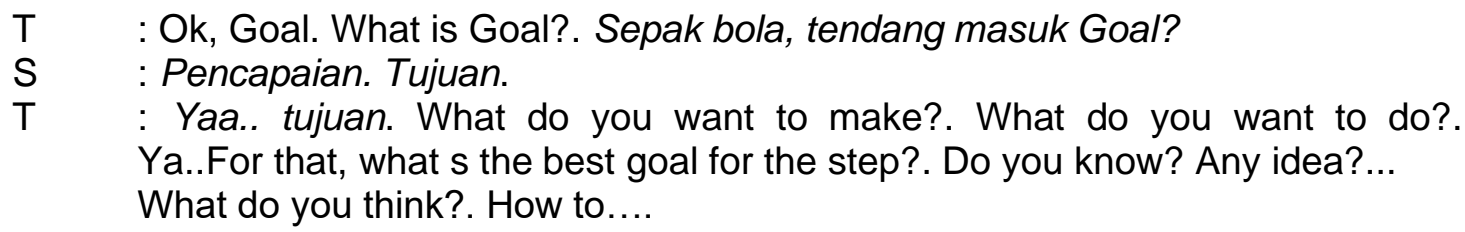

The teacher explained and conveyed what she means with goal by using more related words. Though, the students had already known the meaning of 'goal', the teachers elaborated the meaning she wanted to convey in more words. Third, the clarification request was used to check whether the listener understanding or their comprehension was right or no. This type of communication strategy used by the teacher to clarify the understanding and comprehension of her students after the topic being explained.

$\mathrm{T} \quad$ : Yes, of course shoes. Can you mention again? You (pointing a student in the middle), please mention the 3 materials I mentioned before. Mention.. (her hand is ready to count). Mention.. First.. 
S1 : Take the.. ?

$\mathrm{T} \quad$ : Eh no.. the materials.. not the steps. The materials.. Materialnya..

The clarification request used by the student to check whether her given answer was the expected answer from the teacher. Though it was not used by the teacher, but this type of communication strategy used in the learning process. Fourth, the comprehension check. This type of communication strategy used by the teacher to check her students comprehension about the topic given

$\mathrm{T}$ : Is it clear now? Yang mana Goal, Steps, Materials. Do you understand? Materials ini biasanya isi apa? Bahan dan..

According to Tarone (1980); Bialystok (1990); Dornyei (1995) as cited in Sucipto (2012), comprehension check is the way that speaker do in checking the listeners' understanding or the listener' comprehension. Fifth, the language switching is a strategy where the speaker uses another language, mostly in their mother tongue, to convey the meaning. This strategy was often used by the teacher in the classroom because English is a foreign language and in some occasions it was difficult to be understood by the students.

T $\quad$ : Finally, akhirnya.. Silahkan pakai perintah itu untuk text yang kalan bikin nanti. Okay? We back again ( while pointing at the power point). Next, nah tadi sudah. Can you mention the materials? What are the materials?

S : Shoes..

It was found that the word "Finally" direcly switch into Bahasa Indonesia, the teacher's and students' mother language akhirnya. Then, in conversation the teacher also used language switching from Bahasa Inonesia“ada langkah - langkahnya?' to English with 'Is there any steps?'. Sixth, the paralanguage is a useful communication strategy to guide students to understand the word without translating it into the mother tongue. Paralanguage use non linguistics resources like using gesture and facial expressions.

T : Yaaa.. shorts or skirt. Terus apa lagi? What else?

S : Belt..

$\mathrm{T} \quad$ : Yaa belt (moving her hands in circle around the waist). And then?Wearing shocks and your.

The teacher made a gesture used her hands to emphasize the meaning to make all the students understood. Seventh, the topic avoidance. Topic avoidance was used to avoid any difficult topic in which they may have lack of vocabulary mastery. Littlewood (1984) argues that people need to avoid communicating because of their weakness of vocabulary mastery or knowledge of the topic given. But in the classroom that the researcher observed, the topic avoidance used by the teacher to keep the students focused on the topic.

T : What do you wear then?

S : Breakfast..Skirt..Sepatu..

$\mathrm{T} \quad$ : Skirt, or... for the boy? (pointing at the boys

Some students answered the teacher's question with unrelated topic. Therefore the teacher should avoid the word and mentioned the one related to the topic. The teacher directly avoided the topic because the student mentioned the unrelated sentences to the 
topic requested by the teacher. The teacher used topic avoidance to keep the students focus to the topic

In order to find out the communication strategy which was most frequently used by the teacher, the researcher accumulated the data gathered. Every communication strategy which was recorded from the first, second, and the third observation were calculated. The result of the accumulation can be seen in the following table:

\begin{tabular}{llllll}
\hline NO & $\begin{array}{l}\text { Communic } \\
\text { ation } \\
\text { Strategies }\end{array}$ & Observation & $\begin{array}{c}\text { Total } \\
\text { Occurre } \\
\text { nces }\end{array}$ \\
\hline 1 & $1^{\text {st }}$ & $2^{\text {nd }}$ & $3^{\text {rd }}$ & \\
\hline & $\begin{array}{l}\text { Approximat } \\
\text { ion }\end{array}$ & 1 & 2 & 1 & 4 times \\
2 & $\begin{array}{l}\text { Circumlocu } \\
\text { tion }\end{array}$ & & 1 & & 1 times \\
3 & $\begin{array}{l}\text { Clarificatio } \\
\text { n Request }\end{array}$ & & 1 & & 1 times \\
4 & $\begin{array}{l}\text { Comprehe } \\
\text { nsion } \\
\text { Check }\end{array}$ & 2 & 3 & 2 & 7 times \\
5 & $\begin{array}{l}\text { Language } \\
\text { Switching }\end{array}$ & 2 & 1 & 2 & 5 times \\
6 & $\begin{array}{l}\text { Paralangua } \\
\text { ge }\end{array}$ & 1 & 1 & 1 & 3 times \\
7 & $\begin{array}{l}\text { Topic } \\
\text { Avoidance }\end{array}$ & 1 & 1 & 2 times \\
\hline
\end{tabular}

Based on the data displayed in Table 4.1, it can be concluded that comprehension check was the most frequently used communication strategy applied by teacher when communicating with the students. The total occurrence of this type of the communication strategies were 7 times. The second most frequently used was using the language switching with total occurrences 5 times. After that, approximation came as the third most frequently used with total occurrences 4 times. Then, there was paralanguage with total occurrence of 3 times. Topic avoidance used 2 times and the other communication strategies, such as; circumlocution and clarification request, had the same total occurrences. Each of them was applied 1 time.

After collecting the data of the communications strategies used by the teacher to communicate with the students, the researcher conducted interviews to the teacher. The transcriptions of the interviews were attached in appendices. The recorded interviews were transcribed into written form. After being transcribed, the data were analyzed and investigated in order to know the reason why the teacher used the communication strategies. Approximation used to make the students sure about the explanation by emphasizing the explanation by saying two words with similar meaning, to make the communications clearer. Then circumlocution used to explain an unknown word so the students will understand. It was also useful to avoid unrelated conversation. The clarification request was used to make 
sure that the students clear with the teacher's explanation and to clarify that the teacher had the same understanding with the students. The comprehension check was used to make sure that the students understood about the explanation given by the teacher. So, the goal of the communication in learning a topic was achieved.The language switching was used to communicate well because the students understood about the term (the notion of native speakers). The paralanguage was used to make the communication run well and effectively. To emphasize what teacher wanted to tell in the interactions occurring between the teacher and the students and to make the students understand more. The topic avoidance used to avoid the unrelated conversation, to make the students stay and focus on the disscussed topic.

It was found that the teacher being observed used seven types of communication strategies. They were approximation, circumlocution, clarification request, comprehension check, language switching, paralanguage, and topic avoidance. Based on the researcher's observation, the teacher produced many communication strategies because she had a better chance to be understood by the students.

After being analyzed, the trustworthiness of the data could be seen because in the interview the teacher stated that they used all of the communication strategies proposed by the experts above. The comprehension check was the type of communication strategy which was most frequently used by the teacher. It had the highest total occurrences among the other types proposed by the experts. The comprehension check were applied seven times.. In the second place there was the language switching. After that, there was approximation. It occurred four times. Then the paralanguage with 3 times total occurrence, and followed by the topic avoidance with 2 times total occurrence. Each of the clarification request and circumlocution was applied once.

Besides recording the conversation between the teacher and the students, the researcher also conducted interviews to find out the teacher' reason in applying communication strategies to communicate with students. The interviews were done to the teacher being observed by using some instruments like video recorder and interview guidance.

The results of the interview show two main reasons for the teacher in applying communication strategies. The first was to run the communication well and effectively with the students. It included emphasizing the utterances. In order to achieve that, the teacher used communication strategies. The teacher stated that the comprehension check helps her to keep the students in check. By clarifying the students' understanding, the teacher could decide whether she could go further to the next topic or stay. The goal of the teacher was to ensure that all of her students could catch the topic well, so the comprehension check was used the most during the learning process.

The second main reason was to avoid misunderstanding. Language switching was used to make sure that the teacher understanding was similar to the students'. English is a foreign language for both teacher and students. Using language switching helped the students to understand faster, and besides, as a beginner learners, their mastery of vocabulary were also low. Besides, the topic avoidance was also used with similar reason. It was applied by teacher to avoid misunderstanding in the teaching and learning process. Circumlocution andapproximation were also used with the same reason. 


\section{CONCLUSION AND SUGGESTION}

Based on the findings and discussions presented earlier, it can be concluded that there were seven types of communication strategies used by the teacher of SMP LAB Singaraja in teaching seventh grade students. They were approximation, circumlocution, clarification request, comprehension check, language switching, paralanguage, topic avoidance, and using pictures or objects in conveying message.

Among those types of communication strategies, the accumulation of the data gathered showed that the comprehension check was the type of the communication strategy that the most frequently used by the teacher to communicate with the students. It was followed by the language switching in the second place, and approximation in the third place The other types of communications strategies such as by the topic avoidance, had 2 times total occurrence. Each of the clarification request and thecircumlocution check was applied once.

There were two main reasons why the teacher applied communication strategies. They were to run the communication well and effectively, and to avoid misunderstanding during the learning process.

\section{REFERENCES}

Avval, S., F. (2012).Communication Strategies in translation: A Review on the Taxonomies from 1977 to 2011. Journal of Siberian Federal University.

Dobao, A. \& Martinez, I. (2006). Negotiating Meaning in Interaction between English and Spanish Speakers via Communicative Strategies .

Hancock, Beverley. 1998. Trent Focus for Research and Development in Primary HealthCare. An Introduction to Qualitative Research. Trent Focus. 
Littlewood, William. (1984). Foreign and Second Language Learning: New York: Cambridge University Pers.

Longworth, G. (2008). Comprehending Speech. University of Warwick. Philosophical Perspective,22.

Pia, J. (2010).Communication Strategies Teacher Use to Build Successful Relationship with Students.

Rodriguez, C. \& Roux, R. (2012).The Use of Communication Strategies in the Beginner EFL Classroom. Gist Education and Learning Research Journal, pp 111-128.

Waghorn, A. \& Stevens, K. (1996). Communication between Theory and Practice: How Students Teachers Develop Theories of Teaching. Australian Journal of Teacher Education Volume 21.

Dornyei, Z. \& Scott, M. (1997). Communication Strategies in a Second Language: Definitions and Taxonomies. Language Learning 47: $173-210$.

Tarone, Elaine (1981). Some Thoughts on the Notion of Communication Strategy. TESOL Quarterly 15 (3): 285 - 295 